\title{
欠发达民族地区高校青年专职思政人员核心职业能力提升保障 体系的构想
}

\author{
诸葛明双 李婕 \\ 右江民族医学院 \\ DOI:10.12238/mef.v3i9.2851
}

\begin{abstract}
[摘 要] 从理论上提出构建欠发达民族地区高校青年专职思政人员核心职业能力提升的目标值、标准、 影响因子、提升度、自信度等可操作量化测量维度和模型保障体系。

[关键词] 目标值; 提升标准及影响因子; 提升度与自信度

中图分类号: G64 文献标识码: A
\end{abstract}

Conception of a Guarantee System for Improving the Core Professional Ability of Young Full-time Ideological and Political Personnel in Colleges and Universities in Underdeveloped Ethnic Regions

Mingshuang Zhuge, Jie Li

Youjiang Medical University for Nationalities

\begin{abstract}
[Abstract] Theoretically, it is proposed to construct the target value, standard, influence factor, promotion degree, self-confidence and other operational quantitative measurement dimensions and model guarantee system for the improvement of the core professional competence of college young full-time ideological and political personnel in underdeveloped ethnic regions.
\end{abstract}

[Key words] target value; raising standards and influence factor; promotion degree and self-confidence

\section{1 研究现状}

高校教师职业能力研究, 涉及内涵 及构成、存在问题及影响因素、实证测 量及对策。吴杨伟（2020）提出高校教 师教学与创新能力和科研能力; 高职教 师职业能力分基本、关键、专属职业能 力, 基本能力不足、关键能力缺失和专 属能力差, 从个人、学校和社会三个原 因层面寻找解决, 职业能力提升发展目 标不明晰、职业生涯发展规划不周全、 持续专业发展动力不足; 探讨职业能力 评价内涵、特征和策略。李运华 (2016) 运用 “教师职业核心能力” 问卷测量教 师职业能力构成。

叶澜先生指出影响课堂教学师生 状态的因素之一: 自信度。高校专职思 政人员核心职业能力研究始于职业自 信研究。赵亚东(2019)分析2000至2018
年教师自信文献, 呈波动趋势, 涉及专 职思政人员职业、专业和教学三个自信 维度, 提出反思与展望: 厘清教师自信 的概念, 建立完整的教师自信理论体 系, 量化研究和质化研究相结合, 视角 更多样。首先, 高校专职思政人员职业 自信研究始于 2016年。支钰如（2016） 分析高校思政课部分青年教师存在的 教学不自信现状及原因, 提高素养、理 论、方法和人格自信。2018年, 关注高 校思政教师的职业自信成为研究聚焦 点, 一方面, 黄杜等 (2019) 探讨高校 思政课教师职业自信的意义与价值、现 状与挑战、成因分析以及提升策略; 另 一方面, 潘开艳 (2018) 探讨高校辅导 员职业自信的现状及提升策略、胜任 力。其次, 高校专职思政人员职业能力 提升是研究热点, 陈晓云 (2017) 指出,
高校思政教师发展分教学、学术和个人 场域能力提升; 王溪 (2015) 指出, 高 校思政教师的能力分基础、核心、关键 和拓展能力提升; 苏亚杰 (2019) 指出, 辅导员的核心职业能力: 思想政治教育 能力, 模块平面分职业核心、特定、基 础、拓展能力。其三, 莫沛 (2018) 提 出增强理论、教学、研究和职业能力自 信等途径提升高职思政教师课堂自信 度。

陈晓云 (2017) 总结, 西方大学教 师职业能力五阶段: 一是 60 年代学者时 代, 提升学术能力; 二是 70 年代教学者 时代, 提升教学能力; 三是 80 年代发展 者时代, 能力开发; 四是 90 年代学习者 时代, 注重学生学习效果; 五是 21 世纪 网络时代, 信息技术运用能力。国外学 者Duli（2019）以教师持续专业发展为 
因变量, 教师职业能力框架为自变量, 探索两者关系; Palermo, et al. (2019) 发现高校教师职业能力对教师 专业发展有较高的内在动机和教学效 用价值。

\section{2 研究述评}

高校思政教师职业能力提升自信 度研究刚起步, 仅对课堂教学能力自信 度研究, 既没深入到问题的内部, 也没 系统的研究, 现有研究论文仅散见于一 般期刊, 高质量的研究较贵乏。高校青 年专职思政人员核心职业能力提升目 标值、标准、影响因子测量、提升度、 自信度等研究领域未得到学者的广泛 重视, 研究缺乏系统和有层次的分析。 已有探索定性的研究多, 实证的研究 少, 经验介绍多, 系统研究少。构建欠 发达民族地区高校青年专职思政人员 核心职业能力提升的目标值、标准、影 响因子、提升度、自信度等可操作量化 测量维度和模型, 进行全面深入探讨意 义重大。

\section{3 研究意义}

从理论上, 探索并建立一套比较系 统的欠发达民族地区高校青年专职思 政人员核心职业能力提升的基本原理 和方法; 欠发达民族地区高校为例，围 绕青年专职思政人员核心职业能力提 升开展实证研究，提出 “青年专职思政 人员核心职业能力提升” 的目标值、影 响因子常模、标准、提升度、自信度, 丰富教师专业素养能力的理论文献。在 实践上, 形成一套简便实用的欠发达民 族地区高校青年专职思政人员核心职 业能力提升的保障体系, 为区域内青年 教师专业素养能力提升提供有效 “视 窗”。于学科上, 开启量化研究新领域, 为《大学思政教师能力计量学》研究奠 定基础。

\section{4 研究对象}

高校专职辅导员职业能力标准等级 分：初、中、高，对应年限1-3年、4-8 年、 8 年以上。研究教师职业发展学者认

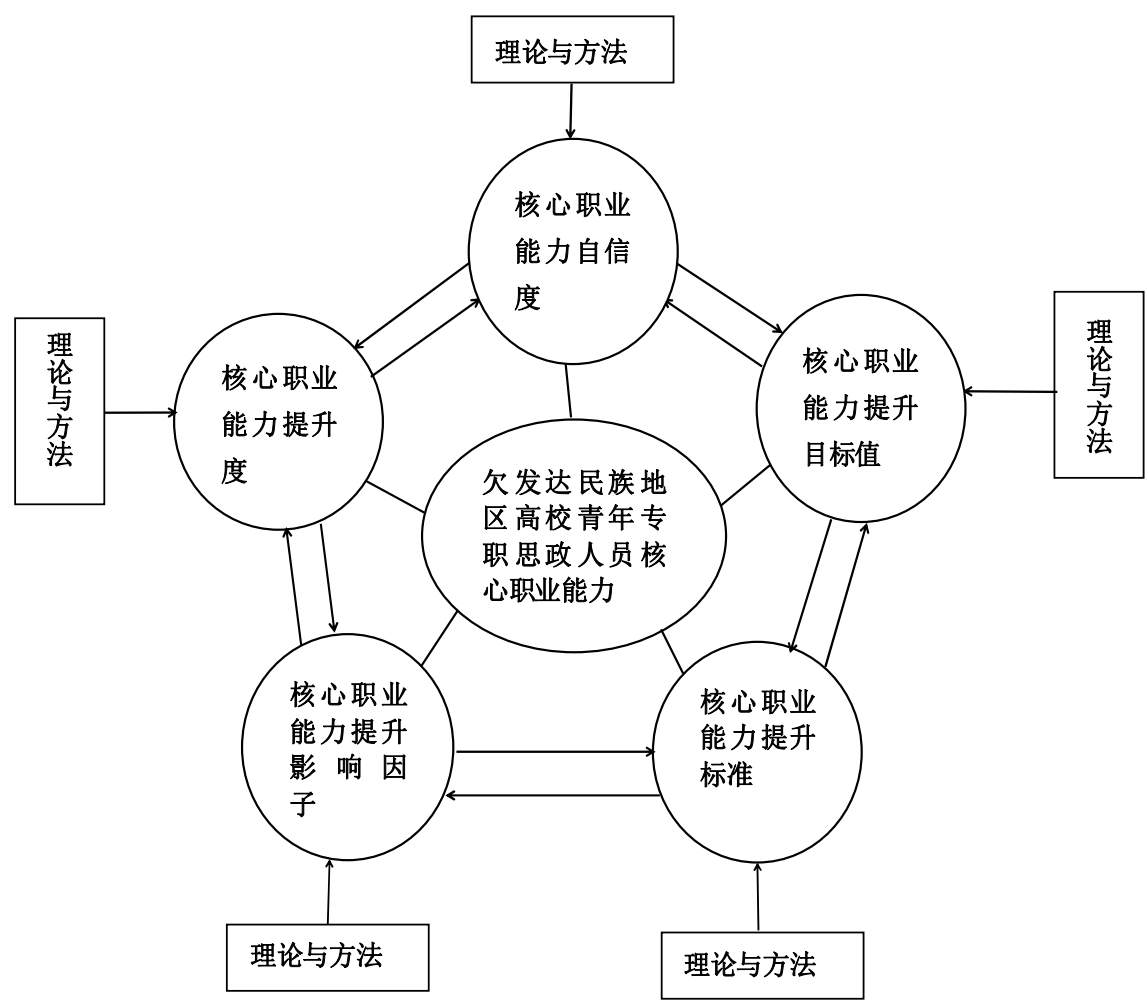

图 1 保障体系

为: 1 年新手阶段、 $2-4$ 年高级新手阶段、 5-7年胜任阶段、8-10年熟练阶段和 10 年以上专家阶段。因此, 8 年教龄是衡量 教师职业成长的分界线, 本文所指高校 青年专职思政人员: 高校从事学生思政 教育的专职思政教师和专职辅导员, 教 龄在8年以内。

\section{5 构建欠发达民族地区高校青} 年专职思政人员核心职业能力提升 超循环保障体系

发达民族地区高校青年专职思政人 员核心职业能力测量与追踪超循环体系 是五部分问题的单向和系统研究组成, 形成一个圈走、环进、旋生的研究体系。 保障体系如图1所示:

一是欠发达民族地区高校青年专职 思政人员核心职业能力提升目标值研 究。“目标值” 是用来描述目标与立德树 人之间功能耦合程度的一个 “数值”。一 是培养什么样的青年专职思政人员核心 职业能力 (一级目标)。二是青年专职思 政人员核心职业能力培养所要达到的程 度 (二级目标)。三是选用什么样评价来
实现知识、能力和素养的有效形成和发 展 (三级目标)。

二是欠发达民族地区高校青年专职 思政人员核心职业能力提升标准研究。 提升标准旨在明析高校青年专职思政人 员核心职业能力发展的选择。一是厘清 青年专职思政人员核心职业能力含什么 能力, 二是厘定青年专职思政人员核心 职业能力提升标准。

三是欠发达民族地区高校青年专 职思政人员核心职业能力提升影响因 子研究。在某一阶段核心职业能力提升 程度和水准, “提升影响因子” 作为重 要视窗和观测点。单个青年专职思政人 员核心职业能力提升影响因子 (K1) = 岗位学历 $(\mathrm{T}) \times$ 专业程度 $(\mathrm{E}) \times$ 身份 $(H) \times$ 科研 $(\mathrm{R}) \times$ 师德 $(M) \times$ 班级 授课规模 $(\mathrm{Q})$ 。其中， $\mathrm{T}$ 分博士、硕士、 大学，按3、2、1赋值; E分本专业或特 长领域、相关相近领域和无相关领域三 级，按3、2、1赋值; H分为教授、讲师 和助教三类，按 $3 、 2 、 1$ 赋值; $R$ 是一学 年完成科研按学校考核所得分; $M$ 是一 
学年履行师德规范按学校考核所得分; Q如以 50 名学生为基准“ 1 ”, 那么, 40-49 名学生为 $0.9 ; 30-39$ 是 $0.8 ; 20-29$ 是 0.7 。相应地, 51-70是 $1.1 ; 71-99$ 是 1.2 ; 100-150是 1.3 。

四是欠发达民族地区高校青年专职 思政人员核心职业能力提升度研究。“提 升度”是指青年专职思政人员设定目标 在一段时间获得发展程度。拟从提升青 年专职思政人员核心职业能力的自我内 驱动力, 基础核心职业能力, 拓展核心 职业能力, 专长核心职业能力等 4 个一级 指标共19个二级指标。

五是欠发达民族地区高校青年专职 思政人员核心职业能力自信度调查研 究。用问卷了解高校青年专职思政人员 核心职业能力自信现状，从基础职业核 心能力、拓展核心职业能力和专长核心 职业能力三个模块分析自信度。

\section{基金项目:}

2018年广西自治区级大学生创新创 业训练计划立项项目: 欠发达地区医科 高校思想政治教育质量提升保障体系的 行动研究一以右江民族医学院为例 (编
号: 201810599074 )；2020年度右江民族 医学院教育教学改革研究课题: 民族地 区医学院校 “思政课程”青年教师核心 职业能力提升的探索与实践 (编号: J2020-33 ) 的阶段性成果之一; 广西高 校中青年教师科研基础能力提升项目 “民族地区青年专职思政人员核心职业 能力提升研究”的阶段性研究成果。

\section{[参考文献]}

[1]吴杨伟.高职院校教师职业能力 评价内涵、特征和策略 [J]. 金华职业技 术学院学报, 2020,20(01):7-11.

[2]赵亚东.近二十年来我国教师自 信研究述评 [J]. 西北成人教育学 报,2019(1):47-53.

[3]黄杜,刘灵。论新时代思政课教师 职业自信的成因分析 [J]. 教育现代 化,2019,6(88):70-71.

[4]潘开艳.新时代增强高校辅导员 职业自信研究[D]. 华中师范大学,2018.

[5]陈晓云.场域理论视域下的高校 思政课教师发展研究 [D]. 华中科技大 学,2017.

[6]苏亚杰. 高校辅导员职业能力研
究[D].哈尔滨师范大学,2019.

[7]莫沛, 李玉伟, 黄小军.高职院 校思想专职理论课教师课堂自信度提升 路径研究 [J]. 和田师范专科学校学 报,2018,37(01):27-31.

[8]Pa Termo C.Thomson M.M.Large -scale Assessment as Professional Development:Teachers' Motivations, Ability Beliefs and Values[J].Teacher Development, 2019,23(2):192-212.

[9]Duli G.C. Teacher Frame Work Competencies Needed for Continuous Professional Deve lopment for Teachers; A Survey[J]. International Journal of Advanced Research in Management and Social Sciences,2019,8(6):33-44.

\section{作者简介:}

诸葛明双（1987-- ), 男，汉族， 广西桂林人, 讲师, 硕士, 研究方向: 思政教育、党建管理。

李婕（1989--)，女，瑶族，广西 梧州人, 讲师, 硕士, 研究方向: 思政 教育、就业管理。 